\title{
CYTOGENETIC ANALYSIS OF THE NEOTROPICAL SPIDER Nephilengys cruentata (ARANEOMORPHAE, TETRAGNATHIDAE): STANDARD STAINING, NORS, C-BANDS AND BASE-SPECIFIC FLUOROCHROMES
}

\author{
ARAÚJO, D., ${ }^{1}$ CELLA, D. M. ${ }^{1}$ and BRESCOVIT, A. D. ${ }^{2}$ \\ ${ }^{1}$ Universidade Estadual Paulista, UNESP, Instituto de Biociências, Departamento de Biologia, \\ Av. 24A, 1515, CEP 13506-900, Rio Claro, SP, Brazil \\ ${ }^{2}$ Instituto Butantan, Laboratório de Artrópodos Peçonhentos, Av. Vital Brasil, 1500, \\ CEP 05503-900, São Paulo, SP, Brazil \\ Correspondence to: Douglas de Araujo, Universidade Estadual Paulista, UNESP, Instituto de Biociências, \\ Departamento de Biologia, Av. 24A, 1515, CEP 13506-900, Rio Claro, SP, Brazil, e-mail: daraujo@rc.unesp.br \\ Received December 13, 2002 - Accepted December 15, 2003 - Distributed May 31, 2005
}

(With 5 figures)

\begin{abstract}
The aim of this work is to characterize Nephilengys cruentata in relation to the diploid number, chromosome morphology, type of sex determination chromosome system, chromosomes bearing the Nucleolar Organizer Regions (NORs), C-banding pattern, and AT or GC repetitive sequences. The chromosome preparations were submitted to standard staining (Giemsa), NOR silver impregnation, C-banding technique, and base-specific fluorochrome staining. The analysis of the cells showed $2 n=24$ and $2 n=$ 26 chromosomes in the embryos, and $2 \mathrm{n}=26$ in the ovarian cells, being all the chromosomes acrocentric. The long arm of the pairs 1, 2 and 3 showed an extensive negative heteropycnotic area when the mitotic metaphases were stained with Giemsa. The sexual chromosomes did not show differential characteristics that allowed to distinguish them from the other chromosomes of the complement. Considering the diploid numbers found in $N$. cruentata and the prevalence of $\mathrm{X}_{1} \mathrm{X}_{2}$ sex determination chromosome system in Tetragnathidae, $N$. cruentata seems to possess $2 n=24=22+X_{1} X_{2}$ in the males, and $2 \mathrm{n}=26=22+\mathrm{X}_{1} \mathrm{X}_{1} \mathrm{X}_{2} \mathrm{X}_{2}$ in the females. The pairs 1,2 and 3 showed NORs which are coincident with the negative heteropycnotic patterns. Using the C-banding technique, the pericentromeric region of the chromosomes revealed small quantity or even absence of constitutive heterochromatin, differing of the C-banding pattern described in other species of spiders. In N. cruentata the fluorochromes DAPI/ DA, DAPI/MM and $\mathrm{CMA}_{3} / \mathrm{DA}$ revealed that the constitutive heterochromatin is rich in AT bases and the NORs possess repetitive sequences of GC bases.
\end{abstract}

Key words: chromosome, Araneae, heterochromatin, secondary constriction, Chromomycin $\mathrm{A}_{3}$.

\section{RESUMO}

Análise citogenética da aranha neotropical Nephilengys cruentata (Araneomorphae, Tetragnathidae): coloração convencional, RONs, bandas C e fluorocromos base-específicos

O objetivo deste trabalho é caracterizar Nephilengys cruentata em relação ao número diplóide, à morfologia cromossômica, ao tipo de sistema cromossômico de determinação sexual, aos cromossomos portadores de Regiões Organizadoras de Nucléolo (RONs), padrão de bandas C e sequiências AT ou GC repetitivas. As preparações cromossômicas foram submetidas à coloração convencional (Giemsa), à impregnação pelo nitrato de prata, técnica de obtenção de bandas $\mathrm{C}$ e à coloração com fluorocromos base-específicos. A análise das células mostrou $2 n=24$ e $2 n=26$ cromossomos nos embriões e $2 n=26$ nas células ovarianas, sendo todos cromossomos acrocêntricos. O braço longo dos pares 1, 2 e 3 apresentou extensa região heteropicnótica negativa quando as metáfases mitóticas foram coradas com Giemsa. Os cromossomos sexuais 
não mostraram características diferenciais que permitissem distingui-los dos outros cromossomos do complemento. Considerando os números diplóides encontrados em $N$. cruentata e a predominância do sistema cromossômico de determinação sexual do tipo $\mathrm{X}_{1} \mathrm{X}_{2}$ em Tetragnathidae, $N$. cruentata parece contar $\operatorname{com} 2 \mathrm{n}=24=22+\mathrm{X}_{1} \mathrm{X}_{2}$ nos machos e com $2 \mathrm{n}=26=22+\mathrm{X}_{1} \mathrm{X}_{1} \mathrm{X}_{2} \mathrm{X}_{2}$ nas fêmeas. Os pares 1,2 e 3 mostraram RONs coincidentes com as regiões heteropicnóticas negativas. Utilizando a técnica de obtenção de bandas $\mathrm{C}$, a região pericentromérica dos cromossomos revelou pequena quantidade ou até mesmo ausência de heterocromatina constitutiva, diferindo do padrão de bandas $\mathrm{C}$ descrito em outras espécies de aranhas. Em N. cruentata, os fluorocromos DAPI/DA, DAPI/MM e $\mathrm{CMA}_{3} / \mathrm{DA}$ revelaram que a heterocromatina constitutiva é rica em bases AT e as RONs apresentam seqüências repetidas de bases GC.

Palavras-chave: cromossomo, Araneae, heterocromatina, constrição secundária, Cromomicina $\mathrm{A}_{3}$.

\section{INTRODUCTION}

The Araneae order has about 38,000 taxonomically known species distributed in 109 families (Platnick, 2002). Of these approximately 460 species have been studied from the cytogenetic point of view, being 32 belonging to the Neotropical region (Hackman, 1948; Suzuki, 1954; Bole-Gowda, 1958; Brum-Zorrila \& Cazenave, 1974; Benavente \& Wettstein, 1980; Brum-Zorrila \& Postiglioni, 1980; Silva, 1988; Scioscia, 1997; Sbalqueiro et al., 1998; Chen, 1999).

In Araneomorphae (suborder Opistothelae), which comprises the highest number of cytogenetically studied species, the diploid number varies from $2 \mathrm{n}=7$, in Ariadna lateralis Karsch 1881, to $2 \mathrm{n}=$ 52, in Agelena naevia Comstock 1912 (Wallace, 1909; Suzuki, 1954). In some families of this last infraorder there is a predominance of a certain diploid number, such as Araneidae $(2 \mathrm{n}=24)$, Gnaphosidae $(2 \mathrm{n}=22)$, Lycosidae $(2 \mathrm{n}=28)$, Oxyopidae $(2 \mathrm{n}=$ $21)$, Pisauridae $(2 \mathrm{n}=28)$, Salticidae $(2 \mathrm{n}=28)$, Tetragnathidae $(2 n=24)$, and Theridiidae $(2 n=22)$, which can represent a more adaptive condition.

The great majority of the cytogenetically described spiders possess acrocentric chromosomes. The sex determination system has been determined in some species of Araneomorphae. About $77 \%$ of the species possess the type $\mathrm{X}_{1} \mathrm{X}_{2} / \mathrm{X}_{1} \mathrm{X}_{1} \mathrm{X}_{2} \mathrm{X}_{2}$ (Hackman, 1948; Suzuki, 1951, 1954; Bole-Gowda, 1958; Mittal, 1966; Datta \& Chatterjee, 1988; Gorlova et al., 1997; Scioscia, 1997), 9\% show the type X/XX (Hackman, 1948; Bole-Gowda, 1958; Suzuki, 1954; Benavente \& Wettstein, 1980; Datta \& Chatterjee, 1983; Rowell, 1985; Gorlova et al., 1997) and 9\% have the type $\mathrm{X}_{1} \mathrm{X}_{2} \mathrm{X}_{3} / \mathrm{X}_{1} \mathrm{X}_{1} \mathrm{X}_{2} \mathrm{X}_{2} \mathrm{X}_{3} \mathrm{X}_{3}$ (Hackman, 1948; Suzuki, 1954; Sharma et al., 1959; Sokolov, 1960, 1962; Datta \& Chatterjee, 1983, 1988; Rowell, 1985). Only 3 species possess the type $\mathrm{X}_{1} \mathrm{X}_{2} \mathrm{X}_{3} \mathrm{X}_{4} / \mathrm{X}_{1} \mathrm{X}_{1} \mathrm{X}_{2} \mathrm{X}_{2} \mathrm{X}_{3}$ $\mathrm{X}_{3} \mathrm{X}_{4} \mathrm{X}_{4}$ (Datta \& Chatterjee, 1983), 5 species possess the type $\mathrm{X}_{1} \mathrm{X}_{2} \mathrm{X}_{3} \mathrm{Y} / \mathrm{X}_{1} \mathrm{X}_{1} \mathrm{X}_{2} \mathrm{X}_{2} \mathrm{X}_{3} \mathrm{X}_{3}$ (Maddison, 1982) and 2 species show the type $\mathrm{X}_{1} \mathrm{X}_{2} \mathrm{Y} / \mathrm{X}_{1} \mathrm{X}_{1} \mathrm{X}_{2} \mathrm{X}_{2}$ (Silva, 1988; Sbalqueiro et al., 1998). Furthermore, the sex determination chromosome system has not been identified in $3 \%$ of the species.

The family Tetragnathidae possesses $2 \mathrm{n}=24=$ $22+X_{1} X_{2}$ in the males, and $2 n=26=22+$ $\mathrm{X}_{1} \mathrm{X}_{1} \mathrm{X}_{2} \mathrm{X}_{2}$, in the females, in 14 of the 20 karyotyped species. In the males of other species of this family, the diploid chromosome number can be $2 n=24=$ $20+\mathrm{X}_{1} \mathrm{X}_{2} \mathrm{X}_{3} \mathrm{X}_{4}$ in Meta segmentata Chyzer \& Kulczynski 1891, 2n $=25=22+\mathrm{X}_{1} \mathrm{X}_{2} \mathrm{X}_{3}$ in Leucauge celebesiana Walckenaer 1842, Leucauge decorata Blackwall 1864 and Leucauge tesselata Thorell 1887, and $2 \mathrm{n}=22=20+\mathrm{X}_{1} \mathrm{X}_{2}$ in Tetragnatha extensa Linnaeus 1758 and Tetragnatha sp. (Tetragnatha obtusa C. L. Koch 1837 or Tetragnatha dearmata Thorell 1873). In all these species the chromosomes are acrocentric (Hackman, 1948; Suzuki, 1951, 1954; Bole-Gowda, 1958; Sharma et al., 1959, 1960; Sokolov, 1960, 1962; Datta \& Chatterjee, 1983, 1988; Gorlov et al., 1995).

The present study was conducted on $N$. cruentata with the purpose of characterizing the karyotype of this species in relation to the diploid number, chromosome morphology, type of sex determination chromosome system, C-banding pattern, and chromosomes bearing the nucleolus organizer regions (NORs), and comparing the karyotype data obtained with those ones of related species described in the literature.

\section{MATERIAL AND METHODS}

The chromosome preparations were obtained from 16 subadult specimens (10 males and 6 
females) and 7 embryos of $N$. cruentata, which were collected in natural populations at the UNESP, Rio Claro, SP, Brazil.

The embryos preparations were performed according to the methodology described by Webb et al. (1978), with some modifications.

The gonadal preparations of subadult specimens were carried out according to the following technique: dissect out the gonads in physiologic solution for insects, transfer the material to colchicin solution $(0.16 \%$ in physiologic solution for insect), leaving for 2 hours, add a volume of hypotonic solution (tap water) equal to that one of colchicine solution for 15 minutes, place the material in a Carnoy I fixative solution for 60 minutes, macerate the material on the surface of the slide in acetic acid $(60 \%)$ and dry the slide in a heating metal plate (35$40^{\circ} \mathrm{C}$ ). The standard staining was accomplished using a 3\% Giemsa solution, for 13-15 minutes. The Cbanding technique was performed according to the methodology described by Sumner (1972), with some modifications. The NOR silver impregnation was made using the method of Howell \& Black (1980), with some modifications. The fluorochrome staining was obtained according to Schweizer (1980) technique. The fluorochromes employed were 4-6 diamin-2 phenylindole (DAPI), Mitramycin (MM), Chromomycin $\mathrm{A}_{3}\left(\mathrm{CMA}_{3}\right)$, and Distamycin (DA).

\section{RESULTS}

\section{Karyotype description}

Mitotic metaphases of $N$. cruentata submitted to the standard staining, C-banding, NOR silver impregnation and fluorochrome technique showed $2 \mathrm{n}=24$ in the male embryos (Fig. 1A) and $2 \mathrm{n}=$ 26 in the female embryos and in the oogonials of the young specimens (Fig. 1B). All chromosomes are acrocentric and decrease gradually in size. The sexual chromosomes do not show differential characteristics that have allowed to distinguish them from the other chromosomes of the complement.

\section{Standard staining}

The analysis of embryonic and oogonial metaphases evidenced that the chromosomes of the pairs 1, 2 and 3 have a prominent negative heteropycnotic region which extends from the median until the telomeric region of the long arm (Fig. 2A, $\mathrm{B})$. The length of this region can vary among different metaphases of the same specimen, being independent of the chromosomal condensation degree. Association between two chromosomes by these negative heteropycnotic regions was noted in a great number of mitotic metaphases, indicating the presence of a special kind of chromatin (Fig. 2C). In several mitotic metaphases, the majority of the chromosomes shows negative heteropycnotic short arms (Fig. 1B). Cells in meiotic division were not found in the male and female gonadal cytologic preparations, probably due to the fact that the gametogenesis occurs in a previous instar to those ones of subadults and adults, which were employed in this study.

\section{C-banding}

In $N$. cruentata, the majority of the chromosomes does not show $\mathrm{C}$ bands in the centromeric region (Fig. 3 ). Evident $\mathrm{C}$ bands occur in the interstitial portion of the long arm in the pairs 1 and 6 , in almost all the extension of the long arm in the pairs 5 and 11, and in the telomeric region of the long arm in the pair 10 . In the chromosomes of the pair 1 , the $\mathrm{C}$ bands are intercalated from the median to the telomeric region of the long arm, and are partially coincident with the negative heteropycnotic region. In the chromosomes of the pair 6 , the $\mathrm{C}$ band is heteromorphic in location (Fig. 3).

\section{Silver nitrate impregnation}

In N. cruentata, the NORs are coincident with the secondary constrictions, which appear in the pairs 1 and 2 (Fig. 4A, B). Embryonic and oogonial metaphases showed a minimum of four and a maximum of five chromosomes bearing the NORs (Fig. 4C, D). In less condensed metaphases, the chromosomes of the pairs 1 and 2 show more than one NOR (Fig. 4B). Interphasic nuclei show a minimum of one and a maximum of nine nucleoli.

\section{Fluorochromes}

In the cells stained with DAPI/MM and analyzed with DAPI filter, the nucleoli in the interphasic nuclei, and the negative heteropycnotic regions in the pairs 1,2 and 3 , are DAPI negative (Fig. 5A). In the metaphasic cells stained with $\mathrm{CMA}_{3} /$ DA, the negative heteropycnotic regions in the pairs 1, 2 and 3 show strong fluorescence, and, additionally, the terminal region of two other chromosomes evidence $\mathrm{CMA}_{3}$ labels (Fig. 5B). With the fluorochromes DAPI/DA, DAPI positive fluorescence in chromosomic elements of the pairs 1,5 , and 6 was verified in mitotic metaphases (Fig. 5C). 


\section{DISCUSSION}

Some karyotypic characteristics of $N$. cruentata, i.e., $2 \mathrm{n}=24$ in the males and $2 \mathrm{n}=26$ in the females, being all the chromosomes acrocentric, are similar to those ones found in the majority of the Tetragnathidae species (Table 1). The accomplished cytogenetic analysis did not allow to establish the type of sex determination chromosome system in $N$. cruentata. However, considering the diploid numbers obtained in the embryos $(2 n=24$ and $2 n=26)$ and in the young females $(2 n=26)$, as well as the literature information about the predominant sex determination chromosome system in the species of Tetragnathidae (Table 1), N. cruentata probably possesses the system $X_{1} X_{2}$ in the males and $\mathrm{X}_{1} \mathrm{X}_{1} \mathrm{X}_{2} \mathrm{X}_{2}$ in the females. The meiotic cells analysis of $N$. cruentata males will certainly contribute for the establishment of this system.

TABLE 1

Tetragnathidae species analyzed from the cytogenetic point of view, with their respective diploid number (2n), sex determination chromosome system (SDS), chromosome morphology $(\mathrm{CM})$ and zoogeographical region $(\mathrm{ZR})$. $\mathrm{A}=$ acrocentric.

\begin{tabular}{|c|c|c|c|c|c|c|}
\hline Species & $\begin{array}{l}2 n \\
(?)\end{array}$ & $\begin{array}{l}\text { SDS } \\
(?)\end{array}$ & $\begin{array}{l}\text { SDS } \\
(?)\end{array}$ & $\mathbf{C M}$ & $\mathbf{Z R}$ & Reference \\
\hline Leucauge blanda & 24 & $\mathrm{X}_{1} \mathrm{X}_{2}$ & $\mathrm{X}_{1} \mathrm{X}_{1} \mathrm{X}_{2} \mathrm{X}_{2}$ & $24 \mathrm{~A}$ & Paleartic & Suzuki, 1954 \\
\hline Leucauge celebesiana & 25 & $\mathrm{X}_{1} \mathrm{X}_{2} \mathrm{X}_{3}$ & $\mathrm{X}_{1} \mathrm{X}_{1} \mathrm{X}_{2} \mathrm{X}_{2} \mathrm{X}_{3} \mathrm{X}_{3}$ & $25 \mathrm{~A}$ & Oriental & Datta \& Chatterjee, 1983 \\
\hline Leucauge decorata & 24 & $\mathrm{X}_{1} \mathrm{X}_{2}$ & $\mathrm{X}_{1} \mathrm{X}_{1} \mathrm{X}_{2} \mathrm{X}_{2}$ & $24 \mathrm{~A}$ & Oriental & Bole-Gowda, 1958 \\
\hline L. decorata & 25 & $\mathrm{X}_{1} \mathrm{X}_{2} \mathrm{X}_{3}$ & $\mathrm{X}_{1} \mathrm{X}_{1} \mathrm{X}_{2} \mathrm{X}_{2} \mathrm{X}_{3} \mathrm{X}_{3}$ & $25 \mathrm{~A}$ & Oriental & Datta \& Chatterjee, 1988 \\
\hline Leucauge tessellata & 25 & $\mathrm{X}_{1} \mathrm{X}_{2} \mathrm{X}_{3}$ & $\mathrm{X}_{1} \mathrm{X}_{1} \mathrm{X}_{2} \mathrm{X}_{2} \mathrm{X}_{3} \mathrm{X}_{3}$ & $25 \mathrm{~A}$ & Oriental & Datta \& Chatterjee, 1983 \\
\hline Meta reticulata & 24 & $\mathrm{X}_{1} \mathrm{X}_{2}$ & $\mathrm{X}_{1} \mathrm{X}_{1} \mathrm{X}_{2} \mathrm{X}_{2}$ & $24 \mathrm{~A}$ & Paleartic & Hackman, 1948 \\
\hline Meta segmentata & 24 & $\mathrm{X}_{1} \mathrm{X}_{2} \mathrm{X}_{3} \mathrm{X}_{4}$ & $\mathrm{X}_{1} \mathrm{X}_{1} \mathrm{X}_{2} \mathrm{X}_{2} \mathrm{X}_{3} \mathrm{X}_{3} \mathrm{X}_{4} \mathrm{X}_{4}$ & $24 \mathrm{~A}$ & Oriental & Datta \& Chatterjee, 1983 \\
\hline Meta segmentata ssp. mengei & 24 & $\mathrm{X}_{1} \mathrm{X}_{2}$ & $\mathrm{X}_{1} \mathrm{X}_{1} \mathrm{X}_{2} \mathrm{X}_{2}$ & - & Paleartic & Sokolov, 1960, 1962 \\
\hline Meta yunohamensis & 24 & $\mathrm{X}_{1} \mathrm{X}_{2}$ & $\mathrm{X}_{1} \mathrm{X}_{1} \mathrm{X}_{2} \mathrm{X}_{2}$ & $24 \mathrm{~A}$ & Paleartic & Suzuki, 1954 \\
\hline Nephila clavata & 24 & $\mathrm{X}_{1} \mathrm{X}_{2}$ & $\mathrm{X}_{1} \mathrm{X}_{1} \mathrm{X}_{2} \mathrm{X}_{2}$ & $24 \mathrm{~A}$ & Paleartic & Suzuki, 1951 \\
\hline Nephila clavata & 24 & $\mathrm{X}_{1} \mathrm{X}_{2}$ & $\mathrm{X}_{1} \mathrm{X}_{1} \mathrm{X}_{2} \mathrm{X}_{2}$ & $24 \mathrm{~A}$ & Oriental & Datta \& Chatterjee, 1988 \\
\hline Nephilengys cruentata & 24 & $\mathrm{X}_{1} \mathrm{X}_{2}(?)$ & $\mathrm{X}_{1} \mathrm{X}_{1} \mathrm{X}_{2} \mathrm{X}_{2}(?)$ & $24 \mathrm{~A}$ & Neotropical & Present Study \\
\hline Pachygnatha clercki & 24 & $\mathrm{X}_{1} \mathrm{X}_{2}$ & $\mathrm{X}_{1} \mathrm{X}_{1} \mathrm{X}_{2} \mathrm{X}_{2}$ & $24 \mathrm{~A}$ & Paleartic & Gorlov et al., 1995 \\
\hline Pachygnatha listeri & 24 & $\mathrm{X}_{1} \mathrm{X}_{2}$ & $\mathrm{X}_{1} \mathrm{X}_{1} \mathrm{X}_{2} \mathrm{X}_{2}$ & $24 \mathrm{~A}$ & Paleartic & Gorlov et al., 1995 \\
\hline Tetragnatha andamensis & 24 & $\mathrm{X}_{1} \mathrm{X}_{2}$ & $\mathrm{X}_{1} \mathrm{X}_{1} \mathrm{X}_{2} \mathrm{X}_{2}$ & - & Oriental & Datta \& Chatterjee, 1983 \\
\hline Tetragnatha extensa & 22 & $\mathrm{X}_{1} \mathrm{X}_{2}$ & $\mathrm{X}_{1} \mathrm{X}_{1} \mathrm{X}_{2} \mathrm{X}_{2}$ & $22 \mathrm{~A}$ & Paleartic & Hackman, 1948 \\
\hline T. extensa & 24 & $\mathrm{X}_{1} \mathrm{X}_{2}$ & $\mathrm{X}_{1} \mathrm{X}_{1} \mathrm{X}_{2} \mathrm{X}_{2}$ & - & Paleartic & Sokolov, 1960 \\
\hline Tetragnatha gracilis & 24 & $\mathrm{X}_{1} \mathrm{X}_{2}$ & $\mathrm{X}_{1} \mathrm{X}_{1} \mathrm{X}_{2} \mathrm{X}_{2}$ & - & Oriental & Datta \& Chatterjee, 1983 \\
\hline Tetragnatha japonicola & 24 & $\mathrm{X}_{1} \mathrm{X}_{2}$ & $\mathrm{X}_{1} \mathrm{X}_{1} \mathrm{X}_{2} \mathrm{X}_{2}$ & $24 \mathrm{~A}$ & Paleartic & Suzuki, 1954 \\
\hline Tetragnatha mandibulata & 24 & $\mathrm{X}_{1} \mathrm{X}_{2}$ & $\mathrm{X}_{1} \mathrm{X}_{1} \mathrm{X}_{2} \mathrm{X}_{2}$ & $24 \mathrm{~A}$ & Oriental & Mittal, 1966 \\
\hline Tetragnatha sp. & 24 & $\mathrm{X}_{1} \mathrm{X}_{2}$ & $\mathrm{X}_{1} \mathrm{X}_{1} \mathrm{X}_{2} \mathrm{X}_{2}$ & - & Oriental & Sharma et al., 1960 \\
\hline Tetragnatha sp. & 24 & $\mathrm{X}_{1} \mathrm{X}_{2}$ & $\mathrm{X}_{1} \mathrm{X}_{1} \mathrm{X}_{2} \mathrm{X}_{2}$ & $24 \mathrm{~A}$ & Oriental & Mittal, 1966 \\
\hline $\begin{array}{c}\text { Tetragnatha sp. } \\
\text { (obtusa or dearmata) }\end{array}$ & 22 & $\mathrm{X}_{1} \mathrm{X}_{2}$ & $\mathrm{X}_{1} \mathrm{X}_{1} \mathrm{X}_{2} \mathrm{X}_{2}$ & $22 \mathrm{~A}$ & Paleartic & Hackman, 1948 \\
\hline Tetragnatha squamata & 24 & $\mathrm{X}_{1} \mathrm{X}_{2}$ & $\mathrm{X}_{1} \mathrm{X}_{1} \mathrm{X}_{2} \mathrm{X}_{2}$ & $24 \mathrm{~A}$ & Paleartic & Suzuki, 1954 \\
\hline
\end{tabular}


In all analyzed specimens of $N$. cruentata, the pairs 1, 2, and 3 always show prominent negative heteropycnotic regions. These regions can be heteromorphic in size, in the same metaphase or among different metaphases, can promote association between two chromosomes, and are strongly impregnated by the silver nitrate, evidencing typical characteristics of secondary constrictions related to NORs.

Information about secondary constrictions in the spider chromosomes are scarce in the literature. There are descriptions concerned to these regions for just six species belonging to the families Heteropodidae (presently Sparassidae) (Rowell, 1985), Araneidae (Datta \& Chatterjee, 1988), Gnaphosidae (Gorlova et al., 1997), Salticidae (Scioscia, 1997), and Oxyopidae (Chen, 1999). In these species, the secondary constrictions are located in different autosomic pairs and/or in the sexual chromosomes, and there is not a distribution pattern of these regions.
The C band pattern obtained in N. cruentata, in other words, the small quantity or even the absence of constitutive heterochromatin in the centromeric region of the chromosomes, the presence of interstitial $\mathrm{C}$ bands in some chromosomes, and chromosomic arms almost totally heterochromatic strongly disagree with the pattern obtained in other species of spiders. In general, the chromosomes of spider species submitted to the $\mathrm{C}$-banding technique have revealed the presence of constitutive heterochromatin in the centromeric region of all chromosomes of the complement and absence of interstitial $\mathrm{C}$ bands (Brum-Zorrilla \& Cazenave, 1974; Brum-Zorrilla \& Postiglioni, 1980; Rowell, 1985; Datta \& Chatterjee, 1988; Gorlova et al., 1997). Additionally, some of these species possess telomeric $\mathrm{C}$ bands in some chromosomes, such as Nephila clavata L. Koch 1878 (Tetragnathidae), which shows additional C bands in the distal region of five chromosomes (Datta \& Chatterjee, 1988).
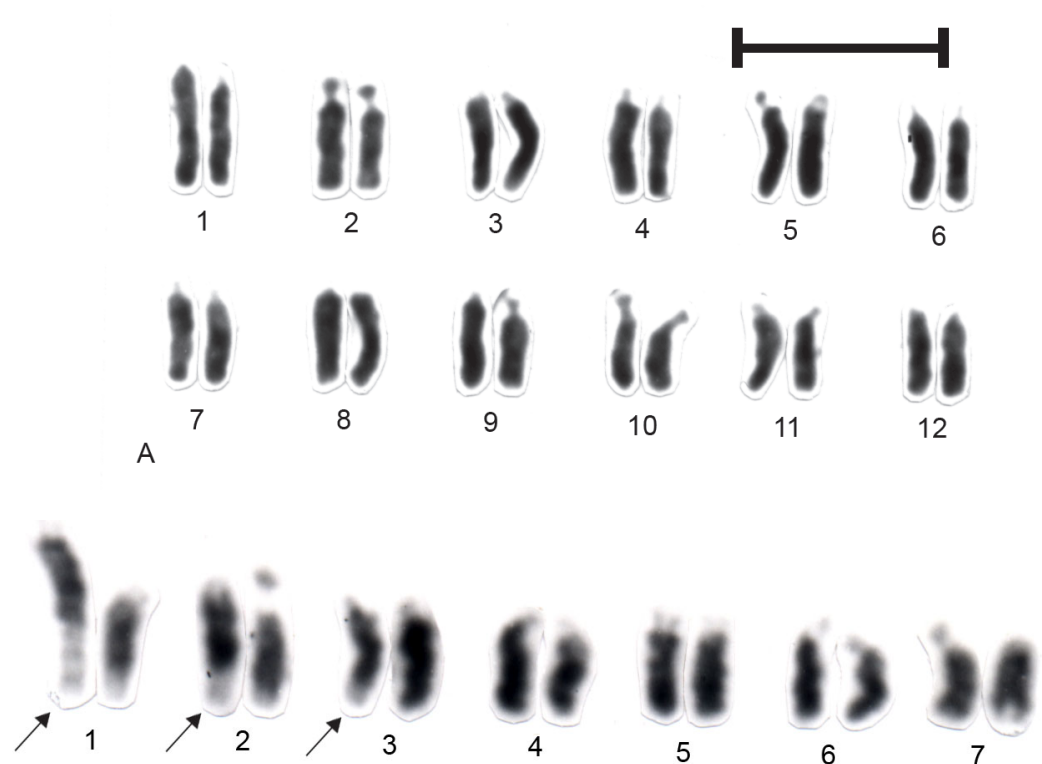

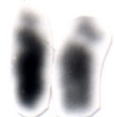

B

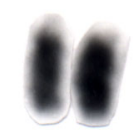

9

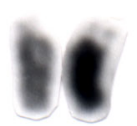

10

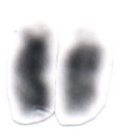

11

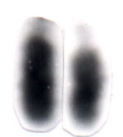

12

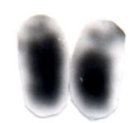

13

Fig. 1 - Karyotype of Nephilengys cruentata conventionally stained. (A) Male embryo, with $2 \mathrm{n}=24$. (B) Young female, with $2 \mathrm{n}=$ 26. Arrows $=$ secondary constrictions. Bar: $10 \mu \mathrm{m}$. 
The small quantity or the absence of constitutive heterocromatin in the centromeric region of the $N$. cruentata chromosomes would be explained by the occurrence of small deletions or by the presence of a special kind of chromatin did not evidence by the $\mathrm{C}$-banding technique employed in this study. The interstitial $\mathrm{C}$ bands in the pairs 1 and 6 and the chromosomic arms almost totally heterochromatic in the pairs 5 and 11 would be a consequence of small duplications. In $N$. cruentata, the heteromorphism of interstitial $\mathrm{C}$ band location in the chromosomic elements of the pair 6 can be explained as a result of structural rearrangement such as paracentric inversion.

The analysis of $N$. cruentata mitotic metaphases and interphasic nuclei, impregnated by the ion silver shows at least six chromosomes bearing the NORs (pairs 1,2 and 3) and one to nine nucleoli, respectively. The numerical variability of the NORs and nucleolar material can be a consequence of the differential activity of the NORs. Furthermore, the nucleoli go through association and dissociation periods, during all the cellular cycle, and its number does not necessarily correspond to the number of chromosomes bearing the NORs (Hsu, 1975; Alberts et al., 2002).

In Araneomorphae, there is little information about the chromosomes bearing the NORs, consequently, there is not a distribution pattern of these regions in the different families. In Dysderidae, one studied species has shown nucleolar material associated to the sexual chromosomes (Benavente \& Wettstein, 1980). In Lycosidae, one species has revealed nucleolar material in the terminal region of two bivalents (Wise, 1983). In Tetragnathidae, the distribution pattern of the NORs is being described for the first time in the $N$. cruentata chromosomes.

In $N$. cruentata, the NORs in the pair 1 seem to be intercalated with constitutive heterochromatin, which could have the function of protecting the NORs against mutations and changes, avoiding alterations in the cistrons of rDNA, as proposed by Yunis \& Yasmineh (1971), Hsu (1975). NORs adjacent to $\mathrm{C}$ bands have also been observed in some insects (Palomeque et al., 1988; Rodríguez-Iñigo et al., 1992; Lorite et al., 1997; Souza et al., 1998).

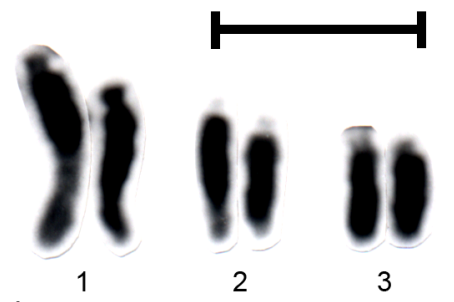

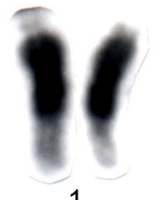

B

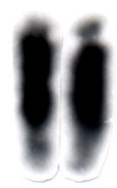

2

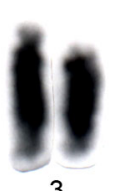

A

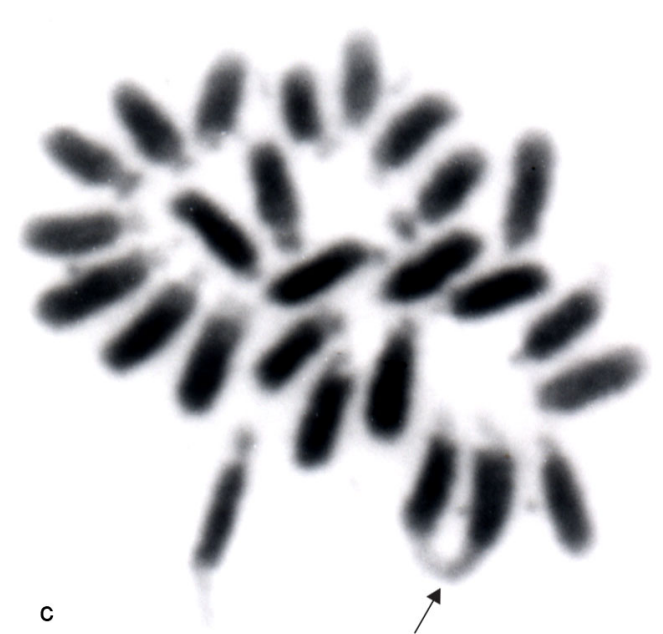

Fig. 2 - Mitotic chromosomes of Nephilengys cruentata submitted to the standard staining. (A-B) Pairs 1, 2 and 3 from different metaphases. (C) Metaphase of young female, with $2 \mathrm{n}=26$, evidencing association between negative heteropycnotic regions (arrow). Bar: $10 \mu \mathrm{m}$. 
The mitotic metaphases of $N$. cruentata submitted to the base-specific fluorochromes DAPI/ MM and analyzed with DAPI filter have evidenced that the negative heteropycnotic regions in the chromosomic pairs 1, 2 and 3 do not posses highly repeated AT base sequences, since these regions are DAPI negative.

This latter datum was confirmed through the analysis of the results obtained with $\mathrm{CMA}_{3} / \mathrm{DA}$ fluorochromes, considering that $\mathrm{CMA}_{3}$ is $\mathrm{GC}$ specific and has positively marked the negative heteropycnotic regions of the pairs 1, 2 and 3. Thus, these results have shown that the NORs in $N$. cruentata possess DNA rich in GC base sequences and poor in AT base sequences. NORs are known to possess GC-rich DNA in several plants (Schweizer, 1976), invertebrates (Schweizer et al., 1983; LopezFernandez et al., 1989; Loreto \& Souza, 2000), and vertebrates species (Schmid, 1980).

The presence of $\mathrm{CMA}_{3}$ positive marks in the terminal region of two other chromosomes of $N$. cruentata would be related to the inactive NORs, considering that these regions were not evidenced by the silver nitrate impregnation, which marks only active NORs in the preceding interphasis according to Miller et al. (1976), Howell (1977) and Schwarzacher et al. (1978), or would represent a special kind of chromatin, rich in GC bases, but not evidenced by the $\mathrm{C}$-banding technique employed in the present study.

The positive marks obtained in the $N$. cruentata chromosomes with DAPI/DA fluorochromes are partially coincident with the C-bands. In the pair 1 , this heterochromatin rich in AT bases seems to precede the negative heteropycnotic region. In the pair 5, the heterochromatic long arm has revealed a rich AT base sequence and the interstitial heterochromatin of the pair 6 has shown a highly repeated AT base sequence.

Up to this moment, there is no cytogenetic analysis in Araneae using base-specific fluorochromes.

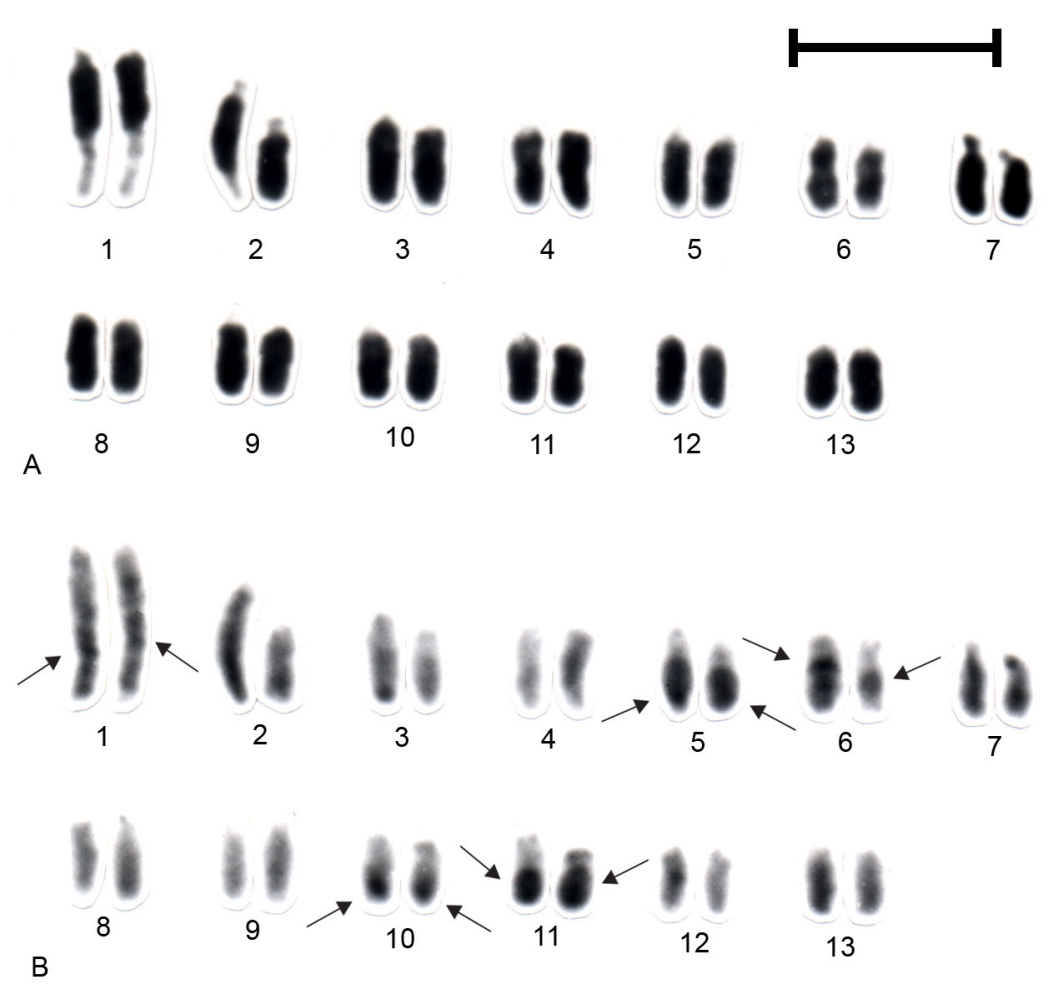

Fig. 3 - Karyotype of Nephilengys cruentata female, with $2 \mathrm{n}=26$. (A) Standard staining. (B) The same karyotype showed in A submitted to the C-banding technique. Arrows $=\mathrm{C}$ bands. Bar: $10 \mu \mathrm{m}$. 
A
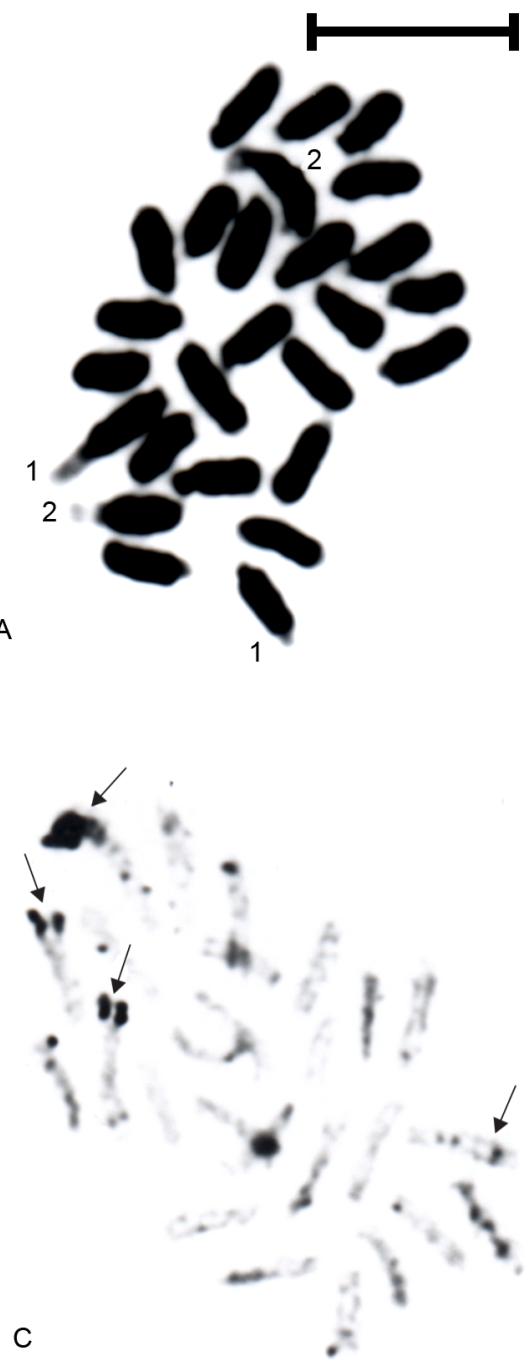
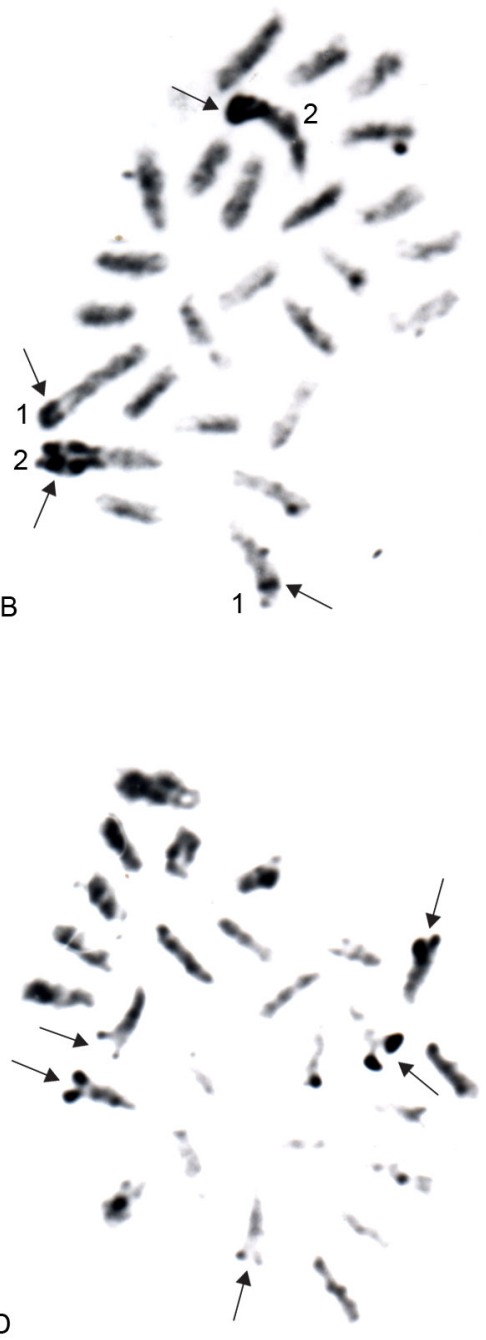

Fig. 4 - Mitotic metaphases of Nephilengys cruentata female, with $2 n=26$. (A) Standard staining. (B) The same metaphase showed in A submitted to the silver nitrate impregnation. (C) With 4 NORs. (D) With 5 NORs. Arrows = NORs. Bar: $10 \mu \mathrm{m}$.

Acknowledgements - The authors thank Departamento de Genética e Evolução, UFSCar, São Carlos, Brazil, for allowing the use of the fluorescence microscopy, and UNESP (Universidade Estadual Paulista), PET/SESu (Programa Especial de Treinamento/
Secretaria de Ensino Superior) and CNPq (Conselho Nacional de Desenvolvimento Científico e Tecnológico) for the financial support. 

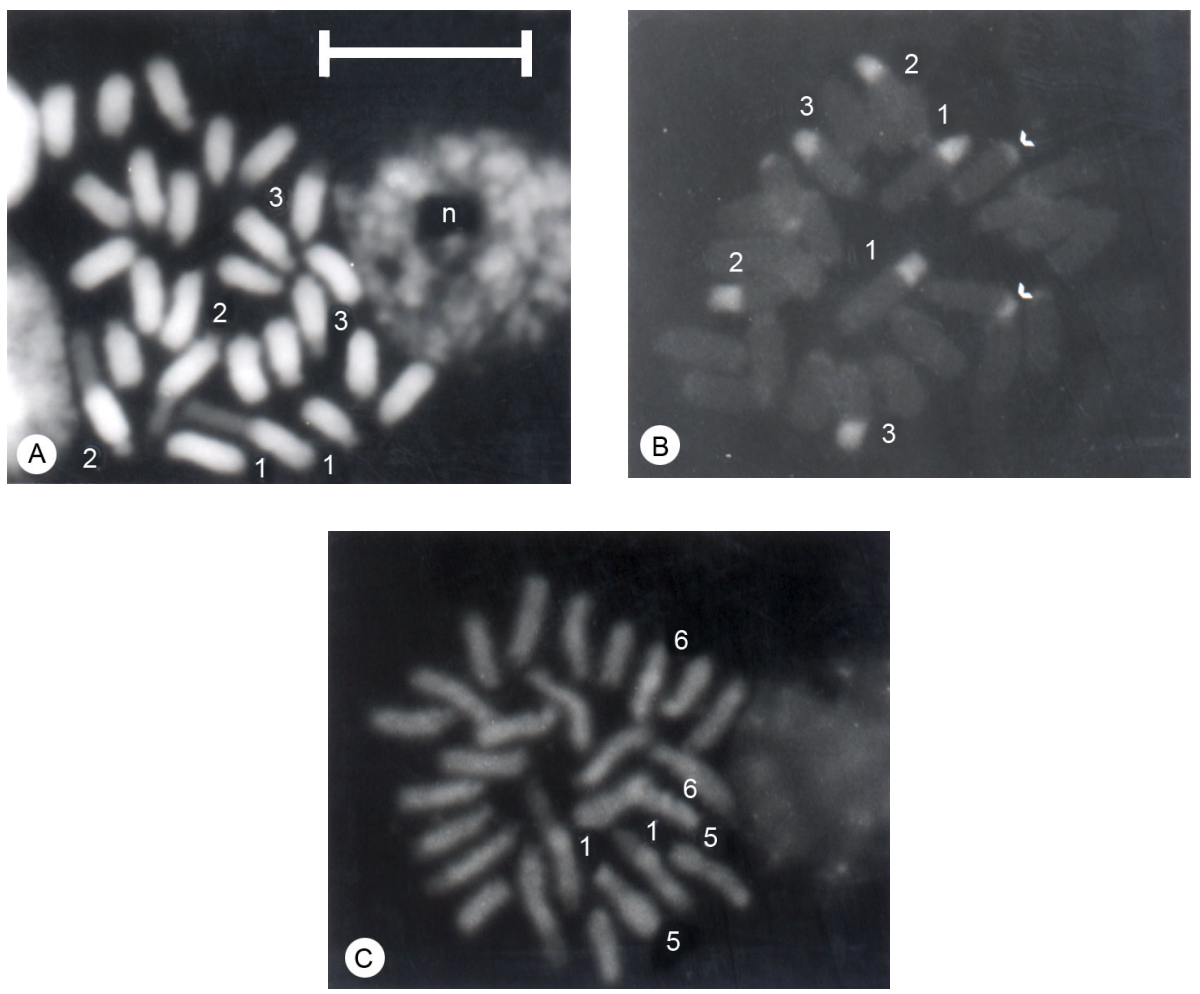

Fig. 5 - Oogonial cells of Nephilengys cruentata submitted to the base-specific fluorochromes. (A) Interphasic nuclei and mitotic metaphase with $2 \mathrm{n}=26$ stained with DAPI/MM, evidencing nucleoli (n) and DAPI negative chromosomic regions in the pairs 1, 2 and 3. (B) Metaphase with $2 \mathrm{n}=26$ submitted to the $\mathrm{CMA}_{3} / \mathrm{DA}$, showing $\mathrm{CMA}_{3}$ positive regions in the pairs 1,2 and 3 , and in an additional chromosomic pair (arrows). (C) Metaphase with $2 \mathrm{n}=26$ stained with DAPI/DA, exhibiting DAPI positive regions in the pairs 1,5 and 6. Bar: $10 \mu \mathrm{m}$.

\section{REFERENCES}

ALBERTS, B., JOHNSON, A., LEWIS, J., RAFF, M., ROBERTS, K. \& WALTER, P., 2002, Molecular biology of the cell. Garland Science, New York.

BENAVENTE, R. \& WETTSTEIN, R., 1980, Ultrastructural characterization of the sex chromosomes during spermatogenesis of spiders having holocentric chromosomes and a long diffuse stage. Chromosoma, 77: 69-81.

BOLE-GOWDA, B. N., 1958, A study of the chromosomes during meiosis in twenty-two species of Indian spiders. In: Proceedings the Zoological Society of Bengal, 11: 69-108.

BRUM-ZORRILLA, N. \& CAZENAVE, A. M., 1974, Heterochromatin localization in the chromosomes of Lycosa malitosa (Arachnida). Experientia, 30: 94-95.

BRUM-ZORRILA, N. \& POSTIGLIONI, A., 1980, Karyological studies on Uruguayan spiders. I. Banding pattern in chromosomes of Lycosa species (Araneae-Lycosidae). Genetica, 54: 149-153.

CHEN, S. H., 1999, Cytological studies on six species of spiders from Taiwan (Araneae: Theridiidae, Psechridae, Uloboridae, Oxyopidae, and Ctenidae). Zoological Studies, 38: 423-434.
DATTA, S. N. \& CHATTERJEE, K., 1983, Chromosome number and sex determining system in fifty-two species of spiders from North-East India. Chromosome Information Service, 35: 69.

DATTA, S. N. \& CHATTERJEE, K., 1988, Chromosomes and sex determination in 13 araneid spiders of North-Eastern India. Genetica, 76: 91-99.

GORLOV, I. P., GORLOVA, O. Y. U. \& LOGUNOV, D. V., 1995, Cytogenetic studies on Siberian spiders. Hereditas, 122: 211220.

GORLOVA, O. Y. U., GORLOV, I. P., NEVO, E. \& LOGUNOV, D. V., 1997, Cytogenetic studies on seventeen spider species from Israel. The Bulletin of the British Arachnological Society, 10: 249-252.

HACKMAN, W., 1948, Chromosomenstudien an araneen mit besonderer berucksichtigung der geschlechtschromosomen. Acta Zoologica Fennica, 54: 1-101.

HOWELL, W. M., 1977, Visualization of the ribosomal gene activity: silver stains proteins associated with rRNA transcribed from oocyte chromosomes. Chromosoma, 62: 361-367. 
HOWELL, W. M. \& BLACK, D. A., 1980, Controlled silver staining of nucleolus organizer regions with protective colloidal developer: a 1-step method. Experientia, 36: 1014-1015.

HSU, T. C., 1975, A possible function of constitutive heterochromatin: the bodyguard hypothesis. Genetics, 79: 137150.

LOPEZ-FERNANDEZ, C., GOSALVEZ, J. \& MEZZANOTTE, R., 1989, Heterochromatin heterogeneity in Oedipoda germânica (Orthoptera) detected by in situ digestion with restriction endonucleases. Heredity, 62: 269-277.

LORETO, V. \& Souza, M. J., 2000, Karyotype, constitutive heterochromatin and nucleolar organizer regions (NORs) in Belosacris coccineipes (Acrididae-Leptysminae). Genetics and Molecular Biology, 23: 575-579.

LORITE, P., ARÁNEGA, A. E., LUQUE, F. \& PALOMEQUE, T., 1997, Analysis of the nucleolar organizing regions in the Tapinoma nigerrimum (Hymenoptera, Formicidae). Heredity, 78: $578-582$

MADDISON, W. P., 1982, XXXY sex chromosomes in males of the jumping spider genus Pellenes (Araneae: Salticidae). Chromosoma, 85: 23-37.

MILLER, D. A., DEV, V. G., TANTRAVHAI, R. \& MILLER, O. J., 1976, Suppression of human nucleolus organizer activity in mouse-human somatic hybrid cells. Experimental Cell Research, 101: 235-243.

MITTAL, O. P., 1966, Karyological studies on the Indian spider. III. Chromosomes and their behaviour during spermatogenesis of two species of the family Tetragnathidae. Genetica, 37: 218-224

PALOMEQUE, T., CHICA, E., CANO, M. A. \& DIAZ-DE-LAGUARDIA, R., 1988, Karyotypes, C-banding and chromosomal location of active nucleolar organizing regions in Tapinoma (Hymenoptera, Formicidae). Genome, 30: 277-280.

PLATNICK, N. I., 2002, The world spider catalog, version 2.5. American Museum of Natural History, on line at http:// research.amnh.org/entomology/spiders/catalog81-87/ index.html.

RODRÍGUES-IÑIGO, E., BELLA, J. L. \& GARCÍA-DE-LAVEGA, C., 1992, Heterochromatin differentiation between two species of the genus Dociostaurus (Orthoptera: Acrididae). Heredity, 70: 458-465.

ROWELL, D. M., 1985, Complex sex-linked fusion heterozygosity in the Australian huntsman spider Delena cancerides (Araneae: Sparassidae). Chromosoma, 93: 169-176.

SBALQUEIRO, I. J., LINZING, S., KLISIOWICZ, D. R. \& MANGILI, O. C., 1998, Sistema cromossômico múltiplo de determinação do sexo do tipo $\mathrm{X}_{1} \mathrm{X}_{2} \mathrm{Y}_{1} \mathrm{X}_{1} \mathrm{X}_{1} \mathrm{X}_{2} \mathrm{X}_{2}$ em Loxosceles intermedia (Araneae: Loxoscelidae). Ciência e Cultura (Suplemento): 1217-1218.

SCHMID, M., 1980, Chromosome banding in Amphibia. IV. Differentiation of G-C and A-T rich chromosome regions in Anura. Chromosoma, 77: 83-103.

SCHWARZACHER, H. G., MIKELSAAR, A. V. \& SCHNEDL, W., 1978, The nature of Ag-staining of nucleolus organizer regions. Cytogenetics and Cell Genetics, 20: 24-39.

SCHWEIZER, D., 1976, Reverse fluorescent chromosome banding with chromomycin and DAPI. Chromosoma, 58: 307-324.
SCHWEIZER, D., 1980, Simultaneous fluorescent staining of $\mathrm{R}$ bands and specific heterochromatin regions (DA-DAPI bands) in human chromosomes. Cytogenetics and Cell Genetics, 27: 190-193.

SCHWEIZER, D., MENDELAK, M., WHITE, M. J. D. \& CONTRERAS, M., 1983, Cytogenetics of the partogenetic grasshopper Warramaba virgo and its bisexual relatives X. Patterns of fluorescent banding. Chromosoma, 88: 227-236.

SCIOSCIA, C. L., 1997, Estudios meióticos en tres especies de Dendryphantinae neotropicales (Araneae, Salticidae): Metaphidippus odiosus, Bryantella smaragdus y Dendryphantes patagonicus. Mendeliana, 12: 97-103.

SHARMA, G. P., JANDE, S. S. \& TANDON, K. K., 1959, Cytological studies on the Indian spiders. IV. Chromosome complement and meiosis in Selenops radiatus Latreille (Selenopidae) and Leucauge decorata Blackwall (Tetragnathidae) with special reference to $\mathrm{X}_{1} \mathrm{X}_{2} \mathrm{X}_{3} 0$ - type of male sex determining mechanism. Research Bulletin of the Panjab University, 10: 73-80.

SHARMA, G. P., TANDON, K. K. \& GREWAL, M. S., 1960, Cytological studies on the Indian spiders. V. Chromosome complement and male meiosis in Hersilia savignyi Lucas (Hersiliidae), Larinia sp. (Argiopidae), Tetragnatha sp. (Tetragnathidae), Oxyopes ryvesii Pocock, and Oxyopes sp. (Oxyopidae). Research Bulletin of the Panjab University, 11: 201-6.

SILVA, D., 1988, Estudio cariotípico de Loxosceles laeta (Araneae: Loxoscelidae). Revista Peruana de Entomologia, 31: 9-12.

SOKOLOV, I. I., 1960, Studies on nuclear structures in spiders (Araneina). I. Karyological peculiarities in spermatogenesis. Voprosy Cytologii i Protistologii, p. 160-186.

SOKOLOV, I. I., 1962, Studies on nuclear structures in spiders (Araneina). II. The sex chromosomes. Tsitologia, 4: 617-625.

SOUZA, M. J., RUFAS, J. S. \& ORELlANA, J., 1998, Constitutive heterochromation, NOR location and FISH in the grasshopper Xyleus angulatus (Romaleidae). Caryologia, 51: 73-80

SUMNER, A. T., 1972, A simple technique for demonstrating centromeric heterochromatin. Experimental Cell Research, 75: 304-6.

SUZUKI, S., 1951, Cytological studies in spiders. I. A comparative study of the chromosomes in the family Argiopidae. Journal of Science Hiroshima University, 12: 67-98.

SUZUKI, S., 1954, Cytological studies in spiders. III. Studies on the chromosomes of fifty-seven species of spiders belonging to seventeen families, with general considerations on chromosomal evolution. Journal of Science Hiroshima University, 15: 23-136.

WALLACE, L. B., 1909, The spermatogenesis of Agalena naevia. Biological Bulletin, 17: 120-160.

WEBB, G. C., WHITE, M. J. D., CONTRERAS, N. \& CHENEY, J., 1978, Cytogenetics of the parthenogenetic grasshopper Warramaba (formely Moraba) virgo and its bisexual relatives. IV. Chromosome banding studies. Chromosoma, 67: 309-339.

WISE, D., 1983, An electron microscope study of the karyotypes of two wolf spiders. Canadian Journal of Genetics and Cytology, 25: 161-168.

YUNIS, J. J. \& YASMINEH, W. G., 1971, Heterochromatin, satellite DNA, and cell function. Science, 174: 1200-1209. 